KAWISTARA

VOLUME 4

No. 2, 17 Agustus 2014

Halaman 111-224

\title{
GERIA PUSAT INDUSTRI BANTEN NGABEN DI BALI PERSPEKTIF SOSIOLOGI KOMODIFIKASI AGAMA
}

\author{
Nengah Bawa Atmadja dan Tuty Maryati \\ Fakultas Ilmu Sosial \\ Universitas Pendidikan Ganesha (Undiksha), Singaraja, Bali \\ Email: nengah_bawa_atmadja@gmail.com.
}

\begin{abstract}
In the 2000s, banten (offerings) of ngaben (cremation), a ritual of death in Balinese community is obtained through market so it creates the commodification of banten. This condition is caused by the characteristics of banten as an economic item, so the Balinese especially women is no longer to be able to make banten, and the expanding of market ideology turns someone to be more comfortable buying banten ngaben rather than making them independently. This condition provides an opportunity for geria (house of the priest) to develop the industry of banten. This is well corresponded with the ideology prevailing in geria, namely market ideology so that they see banten as a source of benefit. The position of geria is stronger than the consumer of banten because geria dominates various capitals, such as economic, social, cultural, and symbolic capital synergistically. As the result, geria as banten manufacturer controls consumer hegemonically. This phenomenon is reflected on the price of banten set by geria and the consumer is just following.
\end{abstract}

Keywords: Ngaben, Market ideology, Hegemony, Banten commodification.

\begin{abstract}
ABSTRAK
Pada tahun 2000-an banten (sesajen) ngaben, yakni ritual kematian pada masyarakat Bali didapat lewat pasar sehingga terjadi komodifikasi banten. Kondisi ini disebabkan oleh karakteristik banten sebagai barang ekonomi, semakin banyak orang Bali terutama perempuan yang tidak bisa lagi membuat banten, dan meluasnya ideologi pasar sehingga seseorang merasa lebih nyaman membeli banten ngaben dari pada membuatnya secara swadaya. Kondisi ini memberikan peluang bagi geria untuk mengembangkan industri banten. Hal ini terkait pula dengan ideologi yang berlaku pada geria, yakni ideologi pasar sehingga mereka melihat banten sebagai sumber keuntungan. Posisi geria lebih kuat daripada konsumen banten karena geria menguasai aneka modal, yaitu modal ekonomi, sosial, budaya,dan simbolik secara bersinergi. Akibatnya, geria sebagai produsen banten menguasai konsumen secara hegemonik. Gejala ini tercermin pada penetapan harga banten, yaitu bergantung pada geria, sedangkan konsumen hanya mengikutinya.
\end{abstract}

Kata Kunci: Ngaben, Ideologi pasar, Hegemoni, Komodifikasi banten. 


\section{PENGANTAR}

Agama Hindu di Bali mengenal banyak jenis yajnya (ritual) antara lain ngaben. Ngaben termasuk yajnya besar sehingga penyelenggaraannya membutuhkan kerja sama antarwarga dadia (klen kecil patrilineal) dan atau desa pakraman (komunitas lokal mengurus masalah adat dan agama) guna mempersiapkan berbagai banten secara gotong-royong (ngayah). Bahan baku banten berasal dari alam sekitar, misalnya janur, buah-buahan, bunga-bungaan, dan lainlain. Begitu pula desa pakraman memiliki banyak serati (tukang banten). Mereka bekerja sama dengan tukang banten dari geria (pendeta Hindu) yang memberikan pelayanan keagamaan kepada anak buahnya (sisya) dengan imbalan berbentuk hormat sosial dan materi, misalnya beras (Atmadja, 2010). Dengan cara ini, maka penyediaan banten ngaben terbebas dari mekanisme pasar sehingga pengeluaran modal finansial bagi pelaku ritual menjadi relatif kecil.

Akan tetapi, sejak tahun 2000-an terjadi perubahan pengadaan banten ngaben, yaitu semakin banyak orang membeli banten daripada membuat banten dengan cara ngayah sehingga muncul komodifikasi banten. Berita tentang orang membeli banten ngaben dengan harga puluhan bahkan ratusan juta rupiah sering terdengar pada masyarakat Bali. Hal ini dikritik oleh berbagai pihak antara lain penganut tattwaisme (beragama menekankan pada filsafat) (Atmadja, 2010). Alasannya, komodifikasi banten dinilai sebagai penyebab kemiskinan mengingat banyak orang ngaben menjual sawah dan atau tegalan. Padahal agama Hindu tidak mewajibkan umatnya ngaben secara besar-besaran. Mereka dapat memilih ngaben tingkatan nista, yaitu ngaben yang lebih menekankan pada esensinya sehingga kebutuhan akan modal ekonomi menjadi lebih kecil. Begitu pula agama Hindu mengajarkan bahwa besaran dana ngaben tidak berkorelasi dengan perolehan surga atau neraka. Surga dan neraka bergantung pada hukum karma phala (Wiana, 1995: 202-208; Atmadja, 2014; Kobelen dan Kowida, 2010: 2; Jendra, 2004). Walaupun demikian bukti-bukti kancah menunjukkan bahwa pembelian banten ngaben dengan harga mahal tetap berlangsung sehingga komodifikasi banten semakin melembaga pada masyarakat Bali.

Komodifikasi banten ngaben dan aneka banten untuk ritual lainnya memunculkan industri banten di geria (rumah tinggal sulinggih atau pendeta Hindu). Industri banten dikritik oleh berbagai pihak antara lain Ida Pandita Mpu Jaya Prema Ananda. Dia menyatakan bahwa pendeta Hindu secara etika tidak boleh berjualan atau tan wenang adol atuku. Pendeta Hindu dilarang pula berusaha dengan maksud mencari untung. Sulinggih hendaknya tidak mengejar keduniawian sebab dapat menimbulkan keresahan dan dirinya pun teragitasi (Suhardana, 2008: 203-287; Wiana, 2004: 237).

Walaupun demikian teks ideal ini tidak sesuai dengan teks sosial karena banyak geria memiliki pabrik banten dengan mempekerjakan tenaga upahan.

Fenomena ini tidak bisa ditutup-tutupi karena sudah terang benderang. Bahkan beberapa geria sudah menetapkan tabel banten. Untuk upacara ini sekian juta, untuk upacara itu sekian juta. Sampai-sampai ada tabel: daksina linggih harganya sekian ribu, banten prayascita sekian ribu. Mirip super market. Kalau begitu kenapa harus menjadi sulinggih, kenapa tidak menjadi makelar banten?

(Ananda, 2011: 1)

Walaupun dikritik oleh berbagai pihak, tetapi geria tetap mengembangkan industri banten. Komodifikasi banten pun semakin semarak di Bali.

Gejala ini memunculkan masalah, yaitu pertama, mengapa orang Bali membeli banten ngaben sehingga melahirkan komodifikasi banten? Kedua, mengapa geria mengembangkan industri banten? Jawaban atas pertanyaan ini amat penting, tidak saja untuk memahami alasan maknawiah konsumen membeli banten dan berkembangnya geria sebagai pusat industri banten, tetapi diharapkan pula memberikan sumbangan bagi pengembangan sosiologi komodifikasi agama. Berkenaan dengan itu maka pemahaman terhadap ritual ngaben tidak lagi terfokus pada aspek agama 
sebagaimana yang berlaku selama ini,tetapi terarah pula pada pemahaman yang bersifat kritis. Dengan cara ini diharapkan mampu menumbuhkan kesadaran pada orang Bali tentang hakikat ritual ngaben dan betapa pentingnya transformasi sosial tentang industri banten yang mengacu kepada tattwa (filsafat) dan susila (etika) dalam agama Hindu.

Untuk menjawab masalah ini digunakan teori sosiologi komodifikasi agama yang dikemukakan oleh Kitiarsa (2013: 983-1018) diperkuat dengan teori globalisasi yang dikemukakan Ritzer (2012), Steger (2005), dan teori strukturalisme konstruktivis dari Bourdieu (1977, 2010) dan berbagai pakar yang membahas gagasan Bourdieu, misalnya Harker, Mahar, dan Wilkes eds., (2009), Lubis (2014), dan lain-lain. Berdasarkan teori-teori ini dibangun paradigma bahwa globalisasi yang berintikan pada ideologi pasar tidak saja menghasilkan manusia yang mendewakan uang, tetapi juga manusia yang terikat pada konsumerisme. Upaya memenuhi kebutuhan dan atau keinginannya mereka bermain pada suatu arena, yaitu pasar. Permainan mereka melibatkan aneka aktor dengan memakai dan atau memperebutkan berbagai modal, yaitu modal ekonomi, sosial, budaya, dan simbolik. Aktor yang mampu mengakumulasikan modal secara lebih banyak berada pada kelas atas dan sekaligus menguasai kelas bawah. Penguasaan ini dilegitimasi secara ideologis sehingga terbentuk hubungan kekuasaan bersifat hegemonik. Pola hubungan kekuasaan seperti ini dapat melahirkan kekerasan, tidak dalam bentuk kekerasan fisik, tetapi berwujud kekerasan simbolik.

Penelitian ini merupakan penelitian kancah memakai pendekatan kualitatif. Informan ditunjuk secara purposif, yaitu orangorang yang pernah membeli banten pengabenan dan geria yang mengembangkan industri banten, ditambah dengan tokoh-tokoh adat dan agama di Bali, misalnya Ketua PHDI Bali, Ketua PHDI Buleleng, pelaku ritual di desa pakraman Bengkala, Buleleng, dan lain-lain. Mereka diwancarai memakai teknik wawancara mendalam. Teknik pengumpulan data lainnya adalah observasi terlibat pada upacara ngaben di berbagai desa/banjar pakraman, misalnya Banjar Pakraman Riang Delod Sema Gede, Penebel, Tabanan. Sumber data lainnya adalah dokumen, misalnya lontar-lontar tentang pengabenan yang tersimpan di Gedong Kirtya, Singaraja, dan buku-buku tentang pengabenan yang tersedia pada perpustakaan pribadi. Aneka sumber data dan atau teknik pengumpulan data ini dipakai secara terpisah atau terpadu dalam konteks triangulasi sehingga kesahihan data menjadi lebih terjamin.

Bertolak dari kerangka teori yang dipakai, yaitu mengarah pada teori sosial kritis, maka sasaran kajian ini tidak hanya membuat deskripsi, tetapi disertai pula dengan metode dekonstruksi (Lubis, 2014: 2-26; Noerhadi, 2013: 232; Faruk, 2012: 172-232). Dengan cara ini maka ideologi ataupermainan kekuasaan, kepentingan, dan hasrat yang tersembunyi di balik komodifikasi banten pada masyarakat Bali dapat dipahami secara lebih mendalam. Pemahaman tidak saja berkaitan dengan makna denotatif, tetapi juga makna konotatif, mencakup di dalam ideologi atau mitos (Fiske, 2004).

\section{PEMBAHASAN}

Ngaben adalah ritual pembakaran jenazah pada masyarakat Bali. Tujuannya, tidak saja mengembalikan badan fisik ke asalnya, tetapi juga mengubah status roh (Atman) orang yang di-aben ke tingkat yang lebih tinggi dan sakral, yaitu menjadi dewa pitara. Dewa pitara berhak untuk dipuja pada sanggah kemulan - tempat suci milik kuren (keluarga batih) atau pura keluarga, yaitu sanggah gede - milik beberapa kuren yang berleluhur sama dilihat dari garis kebapakan atau ke-purusa-an. Pemujaan ini amat penting karena diyakini dapat memberikan kesejahteraan bagi suatu keluarga.

Pada mulanya banten ngaben disiapkan memakai modal sosial, yaitu gotong- royong (ngayah) atau tolong menolong (metulungan) sehingga orang Bali tidak mengenal komodifikasi banten pengabenan. Akan tetapi, seperti disinggung pada uraian di atas, sejak tahun 2000-an terjadi perubahan, yaitu banyak orang Bali membeli banten ngaben sehingga banten menjadi komoditas. 
Hal ini memberikan peluang bagi geria untuk mengembangkan dirinya menjadi pusat industri banten. Analisis data kancah menunjukkan bahwa komodifikasi banten ngaben merupakan gejala sosial budaya yang kompleks yang melibatkan berbagai aspek yang membentuk suatu hubungan bersinergi, seperti terlihat pada Bagan 1 .

\section{Alasan Konsumen Membeli Banten}

Bagan 1 menunjukkan bahwa konsumen banten ngaben adalah kuren (keluaga batih). Gagasan ini berkaitan erat dengan ajaran agama Hindu bahwa manusia terikat pada pitrarna, yaitu utang kepada orang tua. Alasannya, peran orang tua sangat penting antara lain membesarkan anaknya secara fisikal dan sosiobudaya guna membentuk manusia dewasa - memiliki (sya) karakter sebagai dewa (dewata) sehingga dalam agama Hindu orang tua disebut guru rupaka(Atmadja, 2014; Pulasari, 2013: 129150). Pitra rna mengakibatkan anak wajib membayarnya dengan cara sebagai berikut: pertama, pada saat orang tua masih hidup, anak wajib memberikan asuransi sosial, yaitu memeliharanya agar mereka hidup secara damai. Kedua, pada saat orang tua meninggal, maka anak berkewajiban ngaben dengan segala rangkaiannya, yaitu ngerorasin (memukur) dan majar-majar. Jenazahnya bisa saja terlebih dahulu dikuburkan karena kewajiban, maka cepat atau lambat anak harus meng-aben-kan orang tuannya.

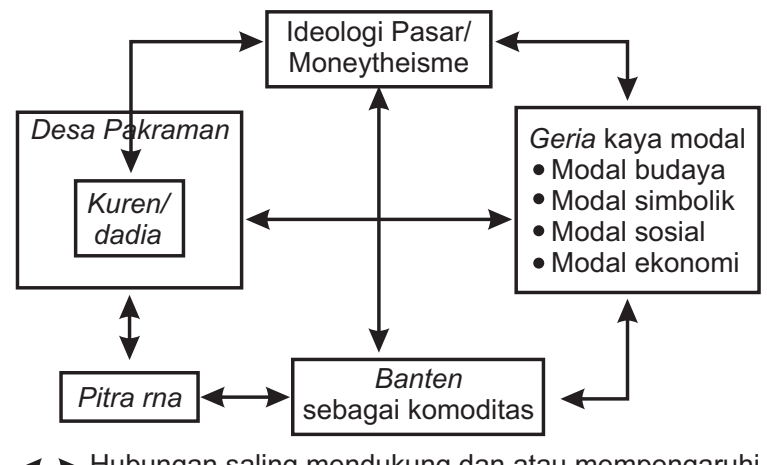

Gambar 1

Model komodifikasi banten ngaben dalam perspektif konsumen dan geria sebagai pusat industri banten.
Jika anak tidak membayar pitra rna, maka orang Bali percaya bahwa mereka akan salahang pitra (disalahkan oleh roh leluhur). Kondisi ini berwujud tertimpa berbagai bentuk kemalangan, misalnya terkena penyakit yang sulit disembuhkan secara medik.Kepercayaan ini tidak saja berdasarkan pada tradisi lokal, tetapi diperkuat pula oleh kitab suci Veda yang menyatakan bahwa penyakit bisa karena roh leluhur marah (Pilkington, 1994:57). Kewajiban ngaben berkaitan pula dengan pembagian harta warisan dalam keluarga. Anak yang melalaikan kewajiban ngaben tidak berhak atas arta warisan yang ditinggalkan oleh orang tuanya. Gagasan ini berkaitan erat dengan konsep harta warisan pada masyarakat Bali, yaitu tidak saja berwujud benda sekala - tanah dan aneka bentuk kekayaaan lain yang bersifat nyata, tetapi juga harta warisan niskala - misalnya kewajiban memuja roh leluhur, termasuk roh suci orang tua dalam pura keluarga berbentuk sanggah kemula (Atmadja, 2010a).

Bagan 1 menunjukkan bahwa setiap kuren adalah anggota dari desa pakramandisebut krama desa pakraman. Keduanya berhubungan secara timbal balik guna menjaga eksistensinya. Kondisi ini berimplikasi bahwa anak yang melalaikan kewajiban ngaben, apalagi yang bersangkutan bermodal ekonomi yang mencukupi, maka warga desa pakraman akan memberikan sanksi negatif berbentuk gunjingan bahkan dapat pula cemohan. Mereka dapat pula dilabeli anak durhaka atau drowaka. Sikap desa pakraman seperti ini bertalian pula dengan keyakinan bahwa roh orang yang tidak di-aben-kan dalam jangka waktu lama dapat berubah menjadi roh kesasar atau lazim disebut bhuta cuil yang berarti roh kotor atau pitra dekot yang dapat mengganggu ketentraman desa pakraman.

Ngaben mutlak membutuhkan banten, sebab banten berfungsi amat penting guna mengalihkan status roh yang di-aben-kan, yaitu dari pitra dekot (roh kotor) menjadi roh suci sehingga berhak memakai gelar dewa pitara dan kuren pun dapat memujanya pada 
sanggah kemulan (tempat suci milik kuren). Pengadaan banten tidak mudah, mengingat gagasan Kitiarsa (2013:996-998) bahwa peralatan ritual ada yang bersifat kelangkaan sehingga berubah menjadi benda ekonomi. Kondisi ini tidak hanya karena banten harus ada dalam upacara ngaben karena dilihat dari aspek nama, rupa, dan nimita - nama, bentuk dan makna banten sangat unik, beragam, dan jumlahnya amat banyak.

Bertolak dari kenyataan ini,maka penyediaan banten ngaben tidak mudah sehingga memerlukan waktu dan tenaga yang banyak. Bahkan yang tidak kalah pentingnya nama, rupa, dan nimita yang rumit memerlukan modal insansi (SDM) yang kaya akan modal kultural agar banten terwujudkan dengan cepat, secara baik dan benar - berpatokan pada pakem banten atau lazim disebut pelutuk banten. Dengan demikian ngaben sebagai kewajiban bagi umat Hindu di Bali - pitra rna yang harus dibayar acap kali dianggap sebagai beban bagi suatu kuren, tidak saja karena banyak menguras tenaga dan waktu, tetapi pula menguras modal finansial (modal ekonomi). Kondisi ini memerlukan cara untuk memecahkannya agar ngaben sebagai kewajiban yang bebasis pitra rna dapat terselenggara secara efektif dan efesien. Pada konteks inilah muncul solusi, yaitu membeli banten sehingga komodifikasi banten ngaben menjadi tidak terhindarkan.

Bagan 1 menunjukkan bahwa kuren berada di dalam suatu unit dadia (klen kecil patrilineal) - keduanya berhubungan secara timbal balik dalam menjaga eksistensinya. Kuren dan dadia berada dalam unit desa pakraman. Dadia dan desa pakraman dapat mengadakan banten secara gratis lewat pemanfaatan modal sosial, berupa gotong royong atau ngayah. Akan tetapi, ngayah mengalami kendala karena adanya diskontinuitas dalam melembagakan tradisi pembuatan banten terutama pada kaum perempuan -pekerjaan perempuan karena menyatu dengan sektor domestik baik pada lingkungan kuren maupun dadia dan desa pakraman. Penyebabnya adalah faktor pendidikan formal sehingga orang Bali terjebak pada pengutuban budaya, yaitu tradisionalitas dan modernitas- menyukai sesuatu yang aktual dan kotemporer, berkebalikan dengan yang lama (Wolton, 2007: 340). Pembuatan banten adalah simbol tradisionalitas, sedangkan komodifikasi benten adalah simbol modernitas. Akibatnya, orang Bali yang memosisikan dirinya sebagai manusia modern lebih suka membeli banten daripada membuat banten ngaben dengan cara ngayah karena terkait dengan modernitas.

Generasi muda Bali yang berpendidikan banyak merantau ke kota, kebanyakan bekerja pada industri pariwisata. Akibatnya, mereka sulit menginvestasikan modal sosial berbentuk ngayah maupun metulungan (tolong menolong) pada lingkungan dadia dan atau desa pakraman. Mereka sibuk bekerja di kota sehingga jarang dapat ngayah dan atau metulungan jika ada warga desa pakraman atau warga dadia yang melakukan ritual ngaben. Kondisi ini dapat menimbulkan kendala dalam menggalang batuan orang lain pada saat yang bersangkutan ngaben- landasan pemberian bantuan adalah modal sosial berwujud resiprositas. Kondisi seseorang yang jarang ngayah dapat mengakibatkan warga desa pakraman tidak optimal bantuannya, bahkan dapat pula menolak untuk membantunya. Banyak kasus di Bali, yaitu suatu kuren mengalami kendala dalam menggalang kerja sama antar-kramadesa pakraman dalam kegiatan ngaben karena dia jarang berpartisipasi dalam kegiatan ngaben yang berlangsung pada lingkungan desa pakraman-nya.

Bertolak dari gagasan ini, maka desa pakraman sebagai lembaga tradisional yang menangani masalah adat dan agama berperan amat penting dalam penyelenggaraan ritual ngaben. Ritual ngaben membutuhkan banyak tenaga sehingga pelibatan krama desa pakraman mutlak adanya. Belum terhitung lagi bahwa desa pakraman memiliki tiga pura, yakni puseh, bale agung, dan dalem - tempat memuja Tri Murti (Brahma, Wisnu, dan Siwa) tempat orang ngaben memohon air suci atau tirtha. Jika tirtha dari tiga pura ini tidak ada maka 
ngaben tidak bisa berlangsung (Atmadja, 2010a). Dengan demikian desa pakraman pada dasarnya memiliki modal sosial, budaya, dan simbolik yang dapat dialihkan menjadi modal kuasa untuk mengatur warganya. Jika desa pakraman menetapkan peraturan bahwa warganya dilarang membeli banten, maka orang pun tidak akan membeli banten, tetapi membuatnya dengan cara ngayah. Keputusan desa pakraman bersifat mengikat secara sosiologis, yuridis, dan religius-magis.

Data kancah menunjukkan belum ada desa pakraman yang melarang warganya membeli banten ngaben. Maka dari itu, desa pakraman di Bali bersifat permisif terhadap kuren yang menyelenggarakan ritual ngaben dengan cara membeli banten. Berkenaan dengan itu, komodifikasi banten ngaben pada masyarakat Bali tidak dapat pula dilepaskan dari kepermisifan desa pakraman. Dengan mengacu kepada Bagan 1 alasan paling penting yang menyebabkan desa pakraman bersifat permisif adalah perluasan ideologi pasar, yaitu tidak saja pada kuren, tetapi juga pada desa pakraman - kuren adalah krama desa pakraman. Anutan ideologi pasar mengakibatkan desa pakraman mempertimbangkan pula untung rugi atau kepraktisan komodifikasi banten tidak saja bagi kuren sebagai pelaku ritual, tetapi juga bagi desa pakraman sebagai lembaga yang ikut terlibat dalam ritual ngaben. Wawancara terhadap beberapa orang bendesa desa pakraman (ketua desa pakraman) menunjukkan bahwa mereka menilai bahwa komodifikasi banten menguntungkan desa pakraman. Sebab, tugas mereka menjadi lebih ringan dilihat dari curahan waktu dan tenaga. Krama desa pakraman tidak perlu ngayah berlama-lama sehingga mereka berpeluang tetap bekerja, walaupun di desanya ada orang ngaben.

Kepermisifan ini terkait pula dengan diferensiasi sosial pada desa pakraman, yaitu warganya tidak lagi homogen sebagai petani, tetapi banyak pula bekerja pada sektor nonpertanian sehingga kepentingan dan sistem pengelolaan waktu dan tenaga mereka secara otomatis beragam pula. Mereka yang bekerja di luar sektor pertanian- terutama pada sektor formal, misalnya sektor pariwisata, tidak dapat diajak ngayah secara terus-menerus karena waktu dan tenaga mereka diatur secara birokratis oleh lembaga tempat mereka bekerja. Jikalaupun mereka ngayah, maka banyak pekerjaan yang sulit dikerjakan oleh warga desa pakraman. Misalnya, naik pohon kelapa untuk mencari janur sangat sulit, sebab semakin jarang orang desa yang berani memanjat pohon kelapa. Dengan demikian janur harus dibeli atau didapat dengan cara memetik memakai buruh panjat sehingga pengeluaran dana bertambah menjadi bertambah besar. Apalagi adanya kenyataan bahwa penyediaan banten pengabenan banyak yang membutuhkan keterampilan khusus sehingga hanya orang tertentu yang dapat dikerjakannya.

Kondisi ini diperkuat pula oleh ideologi pasar atau menyebutnya dengan istilah agama pasar yang semakin melembaga pada masyarakat Bali (Maguire, 2004). Ideologi pasar bertalian dengan berbagai paham lain, misalnya konsumerisme yang antara lain ditandai oleh adanya kenyataan bahwa segala tujuan, aktivitas atau hubungan didominasi oleh jual beli (Ritzer, 2012; Kitiarsa, 2013; Atmadja, 2010; Wibowo, 2010; Lull, 1998; Varela dan Iglesias, 2011). Betapa pentingnya pasar bagi kehidupan umat manusia dapat dicermati pendapat Kitiarsa (2013: 990-991) yang menyatakan bahwa pasar tengah menjadi agama dunia yang pertama bagi umat manusia. Begitu pula Maguire (2004: 19) menyatakan bahwa "... Uang adalah nama Tuhan yang diberikan orang pada agama ini sehingga sekarang bernama moneytheisme". Kondisi ini berlaku pada masyarakat Bali, terbukti dari kenyataan bahwa orang Bali sangat sibuk bekerja agar mendapatkan uang. Kota-kota di Bali memiliki pusat-pusat perbelanjaan, yaitu supermarket dan minimarket. Di desa berkembang turunannya, yaitu toko serba ada (waserda) dan warung serba ada (waserda) sebagai tempat orang desa membelanjakan uangnya.

Penguatan ideologi pasar mengakibatkan modal sosial yang menekankan pada 
resiprositas dan solidaritas sosial - berbasis ideologi kolektivisme menjadi melemah, sebaliknya individualisme menjadi semakin menguat pada masyarakat Bali. Akibatnya, ngayahyang berbasiskan kolektivisme tidak lagi dianggap sebagai kebajikan sosial dalam konteks saling berinvestasi modal sosial, tetapi dianggap sebagai beban sosial dan ekonomi yang menghambat kemajuan. Dengan demikian banyak informan berpendapat bahwa kegiatan membeli banten adalah berkah karena beban sosial berbentuk ngayah menjadi mengecil sehingga penyaluran tenaga dan waktu untuk kepentingan yang bernilai ekonomis menjadi lebih besar - uang pun dapat mengalir ke dalam sistem ekonomi keluarga.

Betapa kuatnya pengaruh ideologi pasar tercermin pula pada pertimbangan bahwa membuat banten dengan cara ngayah dianggap tidak praktis, tidak efesien, dan tidak efektif atau secara umum disebut merepotkan. Alasannya, pertama, membuat banten dengan cara ngayah mengharuskan pelaku ritual menyediakan bahan-bahan banten secara mandiri. Bahan baku banten belum tentu tersedia pada lingkungan sekitar, sehingga pelaku ritual harus membelinya ke pasar. Kedua, pelaku ritual wajib menyediakan konsumsi selama pembuatan banten. Jumlahnya dapat ratusan orang karena orang yang ngayah adalah suami-istri. Kondisi ini banyak menyita waktu dan tenaga sehingga merupakan kendala bagi orang yang bekerja pada sektor formal, yaitu pegawai negeri maupun swasta. Dikarenakan selama warga desa pakraman ngayah, maka pelaku ritual harus ada di rumah guna menyediakan segala hal yang dibutuhkan agar pembuatan banten menjadi lancar. Ketiga, pelaku ritual wajib menunjukkan hormat sosial kepada orang ngayah. Jika pelaku ritual gagal mempertunjukkan hormat sosial, maka warga desa pakraman dapat dikenakan sanksi sosial, yaitu gunjingan, cemohan, bahkan berbentuk pemboikotan sehingga ritual menjadi kacau.

Jika pelaku ritual membeli banten, maka dia hanya tinggal duduk manis sambil menerima pelayat. Banten ngaben sepenuhnya menjadi tanggung jawab geria dan menjelang ritual berlangsung, maka banten diantarkan ke rumah pelaku ritual tanpa biaya tambahan. Pelaku ritual ngaben hanya menyediakan dana sesuai dengan harga banten yang disepakati dengan geria. Jika seseorang tidak memiliki uang, maka desa-desa pakraman di Bali, memiliki Lembaga Perkreditan Desa (LPD) yang dapat memberikan pinjaman dana pengabenan kepada warganya. Pinjaman dapat dikembalikan dengan cara mencicil setiap bulan atau sehabis panen. Walaupun demikian banyak pula orang tidak mampu mencicil utangnya, baik karena pendapatannya yang kecil maupun karena berkembangbiaknya hasrat barang dan jasa yang tersedia di pasar. Akibatnya, banyak orang menjual tanah setelah selesai ngaben, dengan alasan untuk biaya ngaben. Keberlakuan pitra rna mengakibatkan orang Bali dapat menerima penjualan tanah untuk ngaben daripada untuk penyaluran hasrat akan barang-barang konsumtif.

Dengan mengacu kepada Villarino (2011: 19) globalisasi yang berintikan pada ideologi pasar yang menyatu dengan konsumerisme tidak saja mengakibatkan manusia terikat pada jual beli dalam memenuhi kebutuhannya, tetapi melahirkan pula kebiasaan, yaitu "apa yang dimiliki dipamerkan secara terbuka, bahkan dibanggakan". Karakteristik manusia pada era masyarakat konsumen, tidak saja terjebak pada jual beli dan nilai simbolik, tetapi menganut pula budaya tontonan. Dengan demikian timbul manusia yang menganut budaya tontonan sehingga apa yang mereka miliki tidak hanya bernilai guna, tetapi juga bernilai simbolik atau nilai tanda, yaitu berguna untuk menunjukkan gengsi seseorang dalam masyarakat (Atmadja, 2010; Ibrahim, 2007; Piliang, 2012; Villarino, 2011).

Dengan adanya gagasan ini, maka komodifikasi banten tidak hanya karena dorongan nilai agama, tetapi nilai simbolik atau nilai tanda. Gagasan ini tercermin pada desa-desa pakraman di Buleleng, yaitu orang lebih menonjolkan harga banten puluhan atau ratusan juta daripada makna filosofis 
ngaben baik yang menyangkut hakikat ngaben maupun bebantenan-nya. Gagasanini berkaitan erat dengan adanya kenyataan bahwa harga banten ngaben yang mahal merupakan artefak guna mengomunikasikan identitas pelaku ritual baik yang menyangkut kualitas baktinya kepada leluhur maupun kelas sosial, yaitu kaya atau miskin, kesuksesan atau kegagalan seseorang di rantau.

Dengan demikian pelaku ritual menjadi puas - walaupun mengeluarkan dana yang besar, tidak hanya karena mereka dapat membayar utang pada orang tuanya karena yang bersangkutan dapat menunjukkan identitas diri dan keluarganya pada ruang publik. Jika reaksi publik atas pemameran tersebut positif - menunjukkan kekaguman, maka pelaku ritual bertambah besar kepuasannya. Realitas ini memberikan petunjuk bahwa komodifikasi banten ngaben dengan harga yang mahal, tidak hanya karena tuntutan nilai agama, tetapi terselip juga nilai simbolik. Jika masyarakat sebagai penonton terpuaskan, maka pelaku ritual bertambah puas adanya. Oleh karena itu, kepuasan seseorang dalam mengonsumsi banten ngaben dengan harga yang mahal ditentukan pula oleh kepuasan orang lain yang menontonnya pada ruang publik.

Ritual ngaben yang memuaskan penonton pada ruang publik, sangat berpeluang menimbulkan peniruan. Gagasan ini sejalan dengan pendapat Wijayanto (2012, 2013) tentang meme sebagai gen kebudayaan. Dalam konteks ini imitasi (mimesis) kebudayaan dapat mengakibatkan suatu kebudayaan secara cepat diikuti oleh banyak orang, baik dalam bentuk yang sama maupun mengalami adaptasi. Dengan demikian tidak mengherankan jika komodifikasi banten yang semula dilakukan oleh sedikit orang karena mimesis, maka semakin lama semakin banyak orang menerapkannya pada masyarakat Bali.

\section{Geria sebagai Pusat Industri Banten}

Kebutuhan banten pengabenan sebagai suatu keharusan memberikan peluang bagi geria untuk mengomodifikasikan banten lewat pengembangan industri kreatif berbasis budaya bebantenan. Bagan 1 menunjukkan bahwa kondisi ini berkaitan dengan kuatnya pengaruh ideologi pasar, yaitutidak saja pada kuren dan desa pakraman, tetapi juga pada geria. Geria yang di dalamnya terdapat sulinggih atau pendeta (pandita) Hindu bukan dewa, tetapi manusia sehingga tetap terikat pada kama (hasrat). Menurut agama Hindu kama menyatu dengan kehidupan manusia sehingga kama bukan untuk dilenyapkan secara total, melainkan dikendalikan melalui peneguhan dharma atau kebajikan (Atmadja, 2014). Sulinggih sebagai manusia pasti memiliki kama sehingga berpeluang terpengaruh oleh konsumerisme. Apalagi sulinggih memiliki istri, anak bahkan cucu yang secara otomatis juga ber-kama - bujuk rayu konsumerisme melalui iklan (Ihza, 2013). Jadi, geria sebagai arena sosial bagi aktivitas sulinggih dan keluarganya secara substansial, tidak saja merupakan kumpulan manusia, tetapi merupakan pula kumpulan kama sehingga menambah kuatnya godaan konsumerisme di kalangan para sulinggih.

Sistem ekonomi pasar mengakibatkan pemenuhan kama terikat pada uang. Uang harus dicari lewat kerja. Akan tetapi,timbul masalah bagi sulinggih karena sulinggih sebagai orang suci dibebaskan dari pekerjaan-pekerjaan fisik. Untuk menjaga dan meningkatkan kesucian dirinya, maka sulinggih setiap hari wajib melaksanakan pemujaan yang dinamakan surya sewana. Sasarannya, sulinggih mendoakan agar masyarakat dan alam semesta beserta isinya selalu dalam keadaan baik, aman sejahtera, dan damai (Suhardana, 2008: 15). Kewajiban mulia ini menimbulkan dilema karena di satu sisi sulinggih dilarang bekerja secara fisik. Di sisi yang lain sulinggih sebagai manusia memiliki kama dan lebih berat lagi, jika dia memiliki istri, anak, dan cucu sebagai tanggungannya. Akibatnya, banyak geria mengembangkan industri banten sebagai arena untuk memperoleh pendapatan tambahan bagi kelangsungan hidup keluarga. 
Bagan 1 menunjukkan bahwa kegiatan ini tidak dapat dilepaskan dari kepemilikan aneka modal atau sumber daya (Broudieu, 1977, 2010; Haryatmoko, 2010: 13-19; Herker, Mahar dan Wilkes eds., 2009). Modal yang dimiliki oleh geria, yaitu pertama, modal budaya berbentuk pendidikan keagamaan, baik pendidikan formal dan informal maupun nonformal. Suhardana (2012) dan Wiana (2004) memberikan paparan tentang aneka modal budaya yang harus dimiliki oleh sulinggih baik yang menyangkut pengetahuan agama yang bersifat universal maupun yang bersifat khusus guna menjunjung profesinya sebagai sulinggih.

Gelar sulinggih atau secara lebih spesifik, yaitu pedanda (peranda), sri mpu, resi, bhagawan atau dukuh tidak sekedar label, tetapi berfungsi pula sebagai modal budaya.Geria sering pula menyimpan lontar-lontar atau buku-buku agama sebagai pedoman dalam melayani umat Hindu. Kesemuanya ini adalah modal budaya yang amat penting bagi indusri banten di geria. Aneka bentuk modal budaya ini menunjang profesi sulinggih antara lain sebagai lokapalasraya, yaitukewajiban "... memimpin pelaksanaan upacara keagamaan (muput karya), termasuk memberikan petunjuk tentang cara pembuatan banten (upakara), bentuk banten dan jenisnya" (Suhardana, 2012: 184). Modal budaya dan kewajiban lokapalasraya seperti ini secara langsung maupun tidak langsung bisa dimanfaatkan oleh geria untuk menumbuhkembangan industri banten .

Kedua, modal simbolik. Misalnya, gelar sulinggih tidak saja bisa diposisikan sebagai modal budaya, tetapi bisa pula dianggap sebagai modal simbolik. Sebab, kata sulinggih bermakna bahwa yang bersangkutan adalah orang berstatus orang baik dan suci secara lahiriah dan batiniah. Sulinggih disebut pula anaklingsir. Bahkan yang tidak kalah pada saat berbicara dengan orang lain sulinggih menyebut dirinya bapa. Kata lingsir dan bapa adalah gelar simbolik untuk menunjukkan bahwa sulinggih adalah orang tua atau bapa, tidak saja tua atau bapa dalam arti umur, tetapi yang lebih penting adalah tua atau bapa dilihat dari sudut pandang penguasaan agama baik secara kognitif maupun afektif dan psikomotorik. Modal simbolik lainnya adalah bangunan geria yang acap kali dibangun secara megah, nama besar keluargadan status sosial yang tinggi sebagaimana tercermin misalnya pada nama wangsa di Bali, yaitu brahama - wangsa (kasta) yang melahirkan pandita brahmana yang bergelar peranda.

Pakaian sulinggih dalam keseharian di ruang publik antara lain memakai kawaca rajeg berwana putih- simbol kesucian dan membawa tongkat (danda) - simbol orang yang berjalan mengikuti petunjuk dharma (Wiana, 2004). Pada saat sulinggih memimpin ritual (mapuja) memakai bhawa dan bhusana. Bhawa adalah hiasan kepala berbentuk ketu agung - simbol lingga (Siwa). Bhusana adalah hiasan pakaian, misalnya sampet, antinganting (kundala), gelang pada pergelangan tangan (guduhu), ikat pinggang (sabuk), penutup sanggul (amakuta), dan lain-lain. Begitu pula pada saat muput karya sulinggih memakai mudra (sikap tangan) yang sangat unik (Suhardana, 2012: 159-161). Apa pun bhawa, bhusana dan mudra yang digunakan oleh sulinggih pada saat mapuja tidak hanya sebagai teknologi pengelolaan tubuh, tetapi merupakan pula modal simbolik guna menunjukkan ke-sulingih-an kepada umat Hindu pada ruang publik dengan harapan mereka menerimanya sebagai tokoh spiritual yang tidak saja mumpuni, tetapi juga karismatik (Wiana, 2004: 253-258).

Diksa merupakan pula modal simbolik yang tidak kalah pentingnya daripada bhawa, bhusana, dan mudra. Diksa menuntut persyaratan, yaitu sebelum di-diksa seseorang harus belajar agama di bawah bimbingan guru nabe. Pada saat ini yang bersangkutan disebut walaka. Jika guru nabe menilai bahwa walaka sudah dianggap menguasai pengetahuan agama Hindu, maka walaka diperbolehkan melakukan ritual diksa. Diksa terdiri dari serangkaian ritual yang secara esensial memiliki makna simbolik, yaitu tidak untuk menunjukkan bahwa walaka sudah mengusai agama Hindu secara baik, tetapi merupakan 
pula suatu pemberkatan atau pentasbihan dalam konteks pemindahan status seseorang dari walakamenjadi sulinggih. Perpindahan status ini tidak sekedar berganti label, yaitu label walaka diganti dengan label sulinggih dapat pula berlanjut pada gelar-gelar lainnya seperti peranda, mpu, resi, bhagawan, dukuh, dan lain-lain, tetapi disertai pula dengan komitmen yang kuat untuk memahami dan mengaktualisasikan isi yang terkandung pada label sulinggih, yaitu ajaran kebajikan atau dharma (Suhardana, 2011: 163-180; Wiana, 2004: 225-249).

Ketiga, modal sosial antara lain adalah jaringan sosial berbentuk tautan siwa-sisya. Sisya sebagai anak buah (klien) menunjukkan solidaritas sosial terhadap siwa (geria, patron) karena jalinan mereka berasaskan religius magis yang tertuang pada ideologi dana-bhakti (siwa memberikan jasa pelayanan agama = dana dan sisya membalasnya dengan pengabdian $=$ bhakti). Label siwa mencerminkan pula bahwa sulinggih berkedudukan amat penting, yaitu menghubungkan atau bahkan mewakili dewa Siwa sebagai dewa tertinggi dalam aliran Siwa Sidhanta- dominan pada masyarakat Bali dalam berhadapan dengan sisya sebagai anak buahnya (Atmadja, 2010a; Suhardana, 2011). Dewa Siwa sangat penting,tidak saja sebagai dewa tertinggi, juga sebagai titik pusat segala sesuatu (Anandamurti, 2006: 2643). Pada masyarakat Bali siwa dianalogkan pula dengan surya (mata atau matahari). Gagasan ini sejalan dengan kedudukan siwa, yaitu memberikan penerangan berbentuk tuntunan kerohanian dan kepemimpinan ritual bagi umat Hindu -lokapalasraya guna mewujudkan kesejahteraan bagi sisya (Suhardana, 2011: 184).

Dengan demikian tidak mengherankan jika sisya takut meninggalkan siwa-nya karena dapat mengakibatkan kehidupan mereka menjadi gelap-tidak memiliki surya (mata, matahari). Hidup yang gelap ditandai oleh malapetaka, misalnya penyakit yang tidak tersembuhkan, kehidupan ekonomi keluarga yang murat marit, keluarga sering tidak harmonis, dan lain-lain. Modal sosial seperti ini, berpadu dengan modal budaya dan modal simbolik, menumbuhkan modal sosial berbentuk trust (Hasbullah, 2006: 1113). Trust berwujud kepercayaan kepada geria sebagai pusat orientasi dalam ritual sehingga apa pun yang dikemukan oleh geria, maka sisya akan menaatinya secara spontan. Dengan adanya keyakinan ini, maka sisya menunjukkan solidaritas sosial bahkan dapat pula berwujud pengabdian yang tinggi kepada geria dengan harapan siwamemberikan dana (anugrah) sebagaimana tercermin dari kehidupan keluarga mereka yang terang, damai, harmonis, dan sejahtera.

Keempat, modal ekonomi. Modal ini berwujud kepemilikan harta benda pada geria baik yang bersumberkan pada warisan maupun usaha sendiri. Belum terhitung lagi bahwa banyak pandita yang berasal dari pensiunan pegawai negeri atau swasta sehingga modal ekonomi mereka relatif tersedia. Modal ekonomi memberikan peluang bagi geria untuk mendapatkan masukan finansial untuk kepentingan keluarga dan atau untuk menjalankan kegiatan usaha industri banten. Pengetahuan agama dan keterampilan membuat banten dan kepemimpinan ritual, begitu pula jalinan antara siwa dan sisya tidak saja dapat disebut sebagai modal budaya, simbolik dan sosial, melainkan dapat dialihkan pula menjadi modal ekonomi. Jika sisya membeli banten pasti ke siwa-nya sehingga industri banten yang dikelola geria berjalan lancar. Aneka modal ini dikombinasikan dengan modal teknologiper-banten-andan modal insani (tenaga upahan) sehingga terbentuk banten sebagai komoditas guna menghasilkan uang.

\section{Geria Berkuasa Secara Hegemonik}

Komodifikasi banten melibatkan geria atau siwa sebagai pemilik industri banten dan sisya sebagai konsumenbanten. Hubungan mereka beroposisi biner atau ber-rwa bhineda seperti terlihat pada paparan sebagai berikut.

$\begin{array}{ll}\text { Geria } & \text { : Non-geria } \\ \text { Sulinggih } & \text { : Non-sulinggih } \\ \text { Siwa } & \text { : Sisya } \\ \text { Kaya modal } & \text { : Miskin modal }\end{array}$




$\begin{array}{ll}\text { Suci } & \text { : Profan } \\ \text { Dana } & \text { : Bhakti } \\ \text { Patron } & \text { : Klien } \\ \text { Atas } & \text { : Bawah } \\ \text { Menguasai } & \text { : Dikuasai }\end{array}$

Paparan di atas menunjukkan bahwa geria berlawanan dengan non-geria. Di dalam geria terdapat sulinggih dan di luar geria (non-geria) tentu tidak ada sulinggih (nonsulinggih). Hubungan antara geria - nongeria atau sulinggih - non-sulinggih terikat pada hubungan siwa - sisya yang bercorak hubungan patron - klien atau bapak - anak buah. Hubungan ini berkelas karena mereka menguasai akumulasi modal secara berbeda (Bourdieu, 1977, 2010; Haryatmoko, 2010: 13-19; Harker, Mahar dan Wilkes, eds. 2009), yaitu geria berada pada kelas atas, sedangkan sisya berada pada kelas bawah. Posisi geria yang berada pada kelas atas karena geria lebih kaya akan modal daripada nongeria (non-sulinggih, sisya), berupa modal budaya, simbolik, sosial, dan ekonomi. Dengan demikian geria yang disimbolkan dengan sulinggih diposisikan sebagai orang suci, sebaliknya non-geria adalah orang profan. Kesucian mengakibatkan sulinggih bisa memposisikan dirinya mengantarai hubungan antara sisya dengan dewa-dewa dalam ritual. Geria dapat pula memberikan sedekah (dana) kepada sisya antara lain pelayanankeagamaan dan sisya membalasnya dengan bhakti atau pengabdian.

Ketidakseimbangan penguasaan modal tidak saja mengakibatkan geria berada pada kelas atas, tetapi juga menguasai sisya. Akibatnya, hubungan antara geria dan sisya tidak saja berkelas, tetapi juga berdimensi kekuasaan. Basis kekuasaan geria secara esensial adalah modal budaya dan modal simbolik berbentuk pengetahuan agama yang terdapat dalam kitab sucia gama Hindu dan tafsirnya. Penafsiran kitab suci agama Hindu antara lain berbentuk lontar dilakukan oleh geria. Kegiatan ini memberikan peluang kepada geria untuk melakukan penafsiran terhadap kitab suci guna memperkuat posisinya sebagai kelas dominan pada masyarakat Bali. Dengan demikian terbentuk hubungan antara pengetahuan dan kekuasaan (Foucault, 2007).

Kekuasaan menghasilkan pengetahuan yang
dianut (dipaksakan) pada sebagian individu,
sehingga kekuasaan dan pengetahuan
saling mempengaruhi satu sama lain secara
langsung. Tidak ada relasi kekuasaan tanpa
konstitusi korelatif yang berhubungan
dengan pengetahuan; atau pengetahuan
akan membentuk hubungan kekuasaan di
waktu yang sama. Kekuasaan selalu muncul
dan menjadi sistem kontrol. Oleh karenanya,
sistem kontrol dapat menunjukkan sifat
kekuasaan untuk membatasi aktivitas
manusia. Kekuasaan yang berada di mana-
mana menciptakan berbagai wacana yang
mampu mempengaruhi praktik sosial
sehari-hari (Martono, 2014: 49 ).

Wacana berkaitan dengan “... cara berpikir, cara mengetahui dan cara menyatakan sesuatu" (Lubis, 2014: 83). Dalam konteks ini label sulinggih, siwa, anak lingsir, dan lain-lain pada dasarnya dapat diposisikan sebagai wacana. Oleh karena itu,melalui label-label tersebut geria ingin membentuk praksis atau praktik diskursus, yaitu "... jalinan, hubungan antara bahasa, pikiran, pengetahuan, dan tindakan" (Lubis, 2014: 84). Sisya menaruh hormat sosial atau bahkan mengakui kekuasaan geria dengan asumsi bahwa apa yang dikatakan dan atau dilakukan oleh geria adalah benar sehingga harus diterima sebagaimana adanya. Berkenaan dengan itu maka “... wacana menjadi situs penting bagi hubungan pengetahuan, kekuasaan, dan kebenaran" (Lubis, 2014: 84) yang berlaku pada masyarakat Bali dalam konteks hubungan antara siwa dan sisya.

Bertolak dari gagasan ini, maka agama Hindu tidak saja sebagai asas moralitas, tetapi diposisikan pula sebagai ideologi. Pada konteks ini agama Hindu dituangkan dalam bentuk nilai-nilai, norma-norma, keyakinan-keyakinan, mitos-mitos dan tradisi-tradisi, lalu digunakan oleh siwa atau geria untuk melegitimasi kekuasaannya terhadap sisya. Akibatnya, terbentuk hubungan 
kekuasaan yang hegemonik (Gramsci, 2013; Haryatmoko, 2010; Maryani, 2011; Jenks, 2013) antara siwa dan sisya. Pola kekuasaan yang hegemonik mengakibatkan apa pun bentuk tindakan siwa terhadap sisya-nya dianggap sebagai “... cara pandang yang benar (masuk akal)" (Maryani, 2011: 53).

Kondisi ini menimbulkan implikasi terhadap komodifikasi banten, yaitu sisya menerima berapapun harga banten karena banten dianggap baik dan benar. Hal ini secara mudah memunculkan kekerasan ekonomi berupa geria menjual banten dengan harga mahal tanpa disadari oleh sisya yang membelinya. Begitu pula apa pun tindakan geria terutama pandita-nya dianggap masuk akal secara agamawiah sehingga tidak perlu diperdebatkan, kesadaran kritis sisya terhadap siwa-nya menjadi melemah. Dengan meminjam gagasan Bourdieu $(1977,2010)$ dan Lubis (2014: 124) kondisi ini tidak saja memunculkan kekerasan ekonomi, harga banten mahal, tetapi dapat pula memunculkan kekerasan simbolik atau kekerasan lembut yang tidak diakui sebagai kekerasan karena didasarkan atas percaya diri, loyalitas personal, kesediaan menerima, pemberian, utang budi, pengakuan, dan kesalehan yang semuanya diterima sebagai penghormatan bersifat etis. Kekerasan simbolik yang bersifat halus dan atau tersembunyi mengakibatkan sisya menerimanya sebagai suatu kesalehan dalam konteks hubungan siwa-sisya.

\section{Komodifikasi Banten $=$ Komodifikasi Agama}

Banten sebagai peralatan ritual ngaben terikat pada nama (nama), rupa (bentuk), dan nimita (makna). Nimita berkaitan dan atau bersumberkan pada Agama Hindu. Dengan demikian apa pun nama dan rupa suatu banten secara esensial merupakan penjabaran dari Agama Hindu. Jika gagasan ini dikaitkan dengan pendapat Eagleton (2002: 38-61), maka hubungan antara nama, rupa, dan nimita dapat disejajarkan dengan bentuk dan isi. Nama dan rupa adalah bentuk suatu banten dengan label tertentu, sedangkan nimita adalah isi atau kandungan filsafat (tattwa) suatu bantan yang bersumberkan pada agama Hindu, antara lain tercantum pada lontar-lontar. Walaupun keduanya secara teoretis dapat dipilahkan, tetapi realitasnya merupakan satu kesatuan yang tidak terpisahkan.

Bertolak dari gagasan ini, maka komodifikasi banten ngaben, tidak saja menyangkut jual beli banten yang melibatkan konsumen dan geria, tetapi dapat pula disebut komodifikasi agama Hindu - mengingat nama (label banten) dan rupa (bentuk banten) memuat nimita (makna) menurut agama Hindu. Gagasan ini menjadi lebih kuat, jika dikaitkan dengan pendapat Kitiarsa (2013) tentang ciri-ciri komodifikasi agama, yaitu pertama, barang yang dijual adalah simbol agama. Gagasan ini berlaku, mengingat bahwa banten adalah simbol agama Hindu. Kedua, komodifikasi agama terikat pada motif mencari laba. Gagasan ini dapat diterapkan pada kasus komodifikasi banten, mengingat bahwa penjualan banten sebagai suatu kegiatan bisnis dapat dipastikan terarah pada tujuan mencari laba. Apalagi dalam kegiatan industri banten mempekerjakan tenaga upahan - suatu geria di Desa Buruan Gianyar mempekerjakan tenaga upahan mencapai sekitar 50 orang. Ketiga, komodifikasi agama melibatkan suatu institusi keagamaan. Gagasan terlihat pada peran geria. Geria adalah institusi agama Hindu yang berperan menjaga kelangsungan hidup agama Hindu beserta tradisi yang menyertainya. Keempat, komodifikasi agama bersifat terselubung. Gagasan ini berlaku pada komodifikasi banten, yakni geria sebagai penjual banten tidak memakai istilah menjual atau membeli (numbas) banten, melainkan memakai ungkapan nunas banten ke geria (memohon banten ke geria) yang disertai dengan ngaturang jinah (mempersembahkan uang). Dengan demikian komodifikasi banten pada masyarakat Bali tidak saja mengacu kepada aktivitas jual beli banten, melainkan dapat bermakna lebih dalam lagi - sesuai dengan ciri-ciri komodifikasi agama, yaitu apa yang disebut komodifikasi agama Hindu. 
Komodifikasi agama Hindu, tidaklah unik karena berlaku pula pada agama-agama lainnya. Gagasan ini dapat dicermati pada paparan Ibrahim (2007) tentang fenomena agama Islam. Misalnya, banyak orang menghadiri pengajian dengan keharusan membayar mahal pada dasarnya terkait dengan komodifikasi agama. Keikutsertaan seseorang dalam pengajian tidak saja untuk mendapatkan pencerahaan agama, tetapi menyangkut pula peluang untuk mementaskan simbol-simbol agama guna meningkatkan gengsi dalam masyarakat. Begitu pula pemakaian busana Muslimah hasil rancangan artis dan desainer ternama dengan harga yang mahal, tidak hanya untuk menunjukkan ketakwaan, tetapi dapat pula merupakan pemameran status sosial pada ruang publik - berbusana adalah demi gengsi. Gejala ini mencerminkan bahwa komodifikasi agama, tidak saja berlaku pada agama Hindu, tetapi berlaku pula pada agama lain, misalnya Islam.

Komodifikasi agama pada dasarnya berkaitan erat dengan pasar dan konsumerisme. Pasar menyediakan aneka barang konsumsi sesuai dengan apa yang dibutuhkan dan atau diinginkan oleh konsumen. Kejayaan pasar mengakibatkan manusia mengalami komersialisasi dan komodifikasi yang mencakup keseluruhan aspek kehidupannya (Morison, 2012). Dengan adanya kenyataan ini tidak mengherankan jika “... simbol-simbol yang bernuansa agama yang dianggap sakral sekalipun ternyata tidak dapat lepas dari tarikan komersialisasi dan komodifikasi" (Ibrahim, 2007: 162). Perpaduan antara pasar dan konsumerisme melahirkan, memelihara, membentuk dan melanggengkan komodifikasi agama (Kirtiasa, 2013). Gejala seperti ini tidak saja berlaku pada agama Hindu, tetapi juga agama-agama lain, misalnya Islam.

\section{SIMPULAN}

Pelaksanaan ritual ngaben mutlak membutuhkan banten. Pembuatan banten tidak lagi dengan cara ngayah, tetapi dengan cara membeli sehingga timbul komodifikasi banten. Dalam perspetif perspektif konsumen komodifikasi banten disebabkan oleh berbagai faktor, yaitu ngaben sebagai kewajiban yang berbasiskan pitra rna terikat mutlak pada banten. Banten sulit dibuat dengan cara ngayah, karena pengaruh ideologi pasar mengakibatkan orang berpikir praktis, efektif, efesian, cepat atau tidak merepotkan dalam penyelenggaraan ritual, diskontinuitas pengetahuan pembuatan banten sehingga banten ngaben yang dianggap rumit menjadi sulit dibuat, diferensiasisi sosial pada masyarakat desa sehingga orang sulit diajak ngayah untuk membuat banten, desa pakraman bersifat permisif terhadap jual beli banten karena mampu meringankan beban kerjanya, dan penggunaan ngaben sebagai simbol status sosial sehingga membeli banten tidak saja dinilai dari segi nilai agama, tetapi terkait pula dengan gengsi.

Kondisi ini memberikan peluang bagi geria untuk mengembangkan industri banten. Hal ini tidak hanya karena geria terjebak pada ideologi pasar - mencari uang guna memenuhi kebutuhan keluarganya, tetapi juga karena geria memiliki aneka modal, yaitu modal budaya, simbolik, sosial, dan ekonomi. Modal ini dipadukan dengan modal natural, yaitu bahan baku pembuatan banten, diolah dengan menggunakan modal teknologi pembuatan bantensehingga melahirkan banten yang siap dijual kepada konsumen. Aneka modal ini bersinergi dalam konteks memunculkan komodifikasi banten. Hubungan antara sisya sebagai konsumen banten dan geria sebagai produsen banten adalah berdimensi kekuasaan yang berbasiskan pada agama sebagai ideologi sehingga muncul kekuasaan yang hegemonik. Pola kekuasaan seperti ini secara bisa memunculkan kekerasan, berupa kekerasan simbolik yang dilakukan oleh geria terhadap sisya-nya. Penjulan banten tidak saja bermakna komodifikasi banten, tetapi dapat pula bermakna komodifikasi agama. Hal ini berkaitan dengan kenyataan bahwa banten adalah simbol agama Hindu, penjualan banten terkait dengan motif mencari untung yang dilakukan secara tersembunyi oleh suatu lembaga, yakni geria. 


\section{DAFTAR KEPUSTAKAAN}

Ananda, Ida Pandita Mpu Jaya Prema. 2011. Jika Griya Berbisnis Banten. http:// mpuprema.blogspot.com/2011/05/jikagriya-berbisnis-banten.html 22 Juli 2014 (17: 50).

Anandamurti, S. S. 2006. Namah Sivaya Santaya. Surabaya: Paramita.

.2010. Ajeg Bali Gerakan, Identitas Kultural, dan Globalisasi. Yogyakarta: LKiS.

.2010a. Genealogi Keruntuhan Majapahit Islamisasi, Toleransi dan Pemertahanan Agama Hindu di Bali. Yogyakarta: Pustaka Pelajar.

2014. Saraswati dan Ganesha sebagai Simbol Paradigma Interpretativisme dan Positivisme Visi Integral Mewujudkan Iptek dari Pembawa Musibah Menjadi Berkah bagi Umat Manusia. Singaraja: IbIKK Undiksha.

Atmadja, N. B., I W. Sugiartha, Ni M. A. Widiastini. 2014a. .Industri Banten Jaringan Bisnis dan Implikasinya Terhadap Masyarakat Hindu di Bali. Singaraja: Undiksha.

Bourdieu, P., 1977. Outline of Theory of Practice. Cambridge: Cambridge University Press.

1993. The Field of Cultural Production: Essays on Art and Literature. Columbia University Press. Terjemahan Yudi Santoso. 2010.Arena Produksi Kultural sebuah Kajian Sosiologi Budaya. Yogyakarta: Kreasi Wacana.

Eagleton, T. 2002. Marxis and Literary Criticism. Terjemahan Zaim Rafiki. 2002. Marxisme dan Kritik Sastra. Depok: Desantara.

Faruk. 2012. Metode Penelitian Sastra Sebuah Penjelajahan Awal. Yogyakarta: Pustaka Pelajar.

Fiske, J. 1990. Introduction to Communication Studies. 2nd Edition. Routlege. Terjemahan Yosal Iriantara dan Idi Subandy Ibrahim. 2004. Cultural and Communication Studies Sebuah Pengantar Paling Komprehensif. Yogyakarta: Jalasutra.

Foucault, M. 2007.Order of Things An Achaelogy of Human Sciences. Terjemahan B. Priambodo M.S dan Pradana Boy. Order of Thing Arkeologi Ilmu-ilmu Kemanusiaan.(Penerjemah). Yogyakarta: Pustaka Pelajar.

Gramsci, A. 1987. Prison Notebooks. International Publisher. Terjemahan Teguh Wahyu Utomo. 2013. Catatancatatan dari Penajara. Yogyakarta: Pustaka Pelajar.

Haryatmoko. 2010. Dominasi Penuh Muslihat Akar Kekerasan dan Diskriminasi. Jakarta: PT Gramedia Pustaka Utama.

Hasbullah, J. 2006. Social Capital (Menuju Keunggulan Manusia Indonesia). Jakarta: MR-United Press.

Ihza, Y. 2013. Bujuk Rayu Konsumerisme Menelaah Persuasi Iklan di Era Konsumsi. Depok: Linea.

Jendra, I Wyn. 2004. Karmaphala Pedoman dan Tuntunan Moral Hidup Sejahtera, Bahagia dan Damai. Denpasar: Deva.

Jenks, Ch. 1993. Culture. Terjemahan Erika Setyawati.2013. Studi Kebudayaan. Yogyakarta: Pustaka Pelajar.

Kitiarsa, P. 2010. “Menuju Sosiologi Komodifikasi Agama", dalam B. S. Turner eds. 2010. The New Blackwell Companion to the Sociology of Religion. Terjemahan Daryatmo, 2013. Siologi Agama. Yogyakarta: Pustaka Pelajar.

Kobalen, A.S. dan S. Kawida. 2010. Proses Kremasi dan Esensi Perjalanan Menuju Moksha. Surabaya: Paramita.

Lubis, A. Y. 2014. Postmodernisme Teori dan Praktik. Jakarta: PT Raja Grapindo Persada.

Lubis, A. Y. 2014a. Teori dan Metodologi Ilmu Pengetahuan Sosial Budaya Kontemporer. Jakarta: PT Raja Grafindo Persada. 
Mahar, Ch.. R. Harker dan Ch. Wilkes, eds. 1990. An Introduction to the Work of Fierre Bourdieu: The Practice Theory. The Macmillian Press Ltd. Terjemahan Pipiet Maizier. 2009. $($ Habitus $x$ Modal $)+$ Ranah $=$ Praktik Pengantar Paling Komprehensif kepada Pemikiran Bourdieu. Yogyakarta: Jalasutra.

Marguire, D. C. 2000. Sacred Energies. Fortress Press. Terjemahan Ali Noer Zaman, 2004. Energi Suci Kerja Sama Agama-agama untuk Menyelematkan Masa Depan Manusia dan Dunia. Jakarta: Pohon Sukma.

Martono, N. 2014. Sosiologi Pendidikan Michel Foucault Pengetahuan, Kekuasaan, Disiplin, Hukuman dan Seksualitas. Jakarta: PT Raja Grafindo Persada.

Maryani, E. 2011. Media dan Perubahan Sosial Suara Perlawanan Melalui Radio Komunitas. Bandung: PT Rosda Karya.

Morisan. 2012. Periklanan Komunikasi Pemasaran Terpadu. Jakarta: Kecana Prenada Media Group.

Pendit, Nym. S. 1995. Hindu dalam Tafsir Modern. Denpasar: Yayasan Dharma Naradha.

Piliang, Y. A. 2012. Semiotika dan Hipersemiotika Kode, Gaya dan Matinya Makna. Bandung: Matahari.

Pilkington, J. M.1992. Alternative Healing \& Your Health. Diagram Visual Information Limited. Terjemahan Susi Purwoko, 1994. Misteri Pengobatan Tradisional. Jakarta: Arcan.

Pulasari, J. M. 2013. Rare Angon dan Catur Yajnya Bhuta Yajnya, Manusa Yajnya,
Pitra Yajnya, Dewa Yajnya. Surabaya: Paramita.

Ritzer, G. 2011. Sociology Theory. Eight Edition. Publisher by McGrow-Hill. Terjemahan Alimandan. 2012. Teori Soiologi dari Sosiologi Klasik Sampai Perkembangan Terakhir Postmoder. Jakarta: Prenada Media.

Steger, M. B. 2002. Globalism, TheNew Market Ideology. Rowman \& Littlefield Publishers, Inc. Terjemahan Heru Prasetyo. 2005. Globalisme Bangkitnya Ideologi Pasar. Yogyakarta: Lafadl.

Suhardana, K.M. 2011. Dasar-dasar Kesulinggihan suatu Pengantar bagi Calon Sulinggih. Surabaya: Paramita.

Ibrahim, I. S. 2011. Budaya Populer sebagai Komunikasi. Yogyakarta: Jalasutra.

Varela, J. M. V. \& E.B. Eglesias. 2011. Learning to Live: Globalization. Original Edition. Nova Galicia Edicions. Terjemahan Setina Yuda P. 2011. Globalisasi. Jakarta: PT Bhuwana Ilmu Populer.

Villarino, R. R.. 2011. Learning to Live: Consumerism. Original Edition. Nova Galicia Edicions. Terjemahan Septina Yuda P. 2011. Konsumerisme. Jakarta: PT Bhuwana Ilmu Populer.

Wiana, I. K. 2004. Makna Upakara Yajnya dalam Agama Hindu II. Surabaya: Paramita.

Wibowo, I. 2010. Negara Centeng Negara dan Saudagar di Era Globalisasi. Yogyakarta: Kanisius.

Wijayanto, E. 2012. Genetika Kebudayaan Seri 2. Jakarta: Salemba Humanika.

2013. Memetics Perspektif Evolusionis Membaca Kebudayaan. Jakarta: Kepik. 